\title{
A new type of EU visa? The legal nature of a travel permit issued under the European Travel Information and Authorization System (ETIAS)
}

\author{
Nowy rodzaj wizy UE? Charakter prawny zezwolenia na podróż wydawanego w ramach \\ Europejskiego systemu informacji o podróży oraz zezwoleń na podróż (ETIAS) \\ Новый тип визы ЕC? Правовая природа разрешения на поездку, выданного \\ в рамках Европейской системы информации и авторизации путешествий (ETIAS)
}

\author{
MACIEJ CESARZ \\ Dr. habil., University of Wrocław \\ e-mail: maciej.cesarz@uwr.edu.pl, https://orcid.org/0000-0002-9995-719X
}

\begin{abstract}
Summary: The key purpose of ETIAS is the monitoring and selection of persons entering the EU and authorization of entry to its territory. The authors of this new large-scale database project underline clearly that the ETIAS permit is not a visa but should be more accurately referred to as a visa-waiver. However, as an electronic system dedicated to entry authorization linked to the traveler's passport, ETIAS manages the movement across EU external borders of the citizens from 62 third countries, i.e., a population of about 1,4 billion people eligible for visa-free travel. The main aim of the article is to compare Schengen visas and travel authorization that will be issued under ETIAS regulation starting in 2022. The comparative analysis includes several arguments in favour of the thesis that travel decisions issued under the new ETIAS regime fit into the broad legal definition of visas understood as authorization to enter the territory of the European Union.
\end{abstract}

Key words: ETIAS, Schengen visa, EU Integrated Border Management, EU visa policy

Streszczenie: Głównym celem systemu ETIAS jest selekcja i monitorowanie osób przekraczających granicę zewnętrzną Unii Europejskiej poprzez wydawanie zezwoleń na wjazd. Autorzy tego nowego, zakrojonego na szeroką skalę projektu wyraźnie podkreślają, że zezwolenie ETIAS nie jest wizą, niemniej ten kolejny elektroniczny system autoryzacji wjazdu usprawni zarządzanie mobilnością obywateli 62 państw trzecich, a więc populacją 1,4 mld osób uprawnionych do bezwizowego przekraczania zewnętrznych granic UE. Niniejszy artykuł stanowi porównanie wiz Schengen oraz zezwoleń na podróż, które mają zostać wprowadzone na mocy rozporządzenia ETIAS w 2022 r. Analiza porównawcza zawiera szereg argumentów przemawiających za tezą, że zezwolenia wydawane w ramach nowego reżimu ETIAS wpisują się w szeroką definicję prawną wiz rozumianych jako upoważnienie do wjazdu na terytorium UE.

Słowa kluczowe: ETIAS, wiza Schengen, zintegrowane zarządzanie granicami UE, polityka wizowa UE

Резюме: Основной целью ETIAS является отбор и контроль лиц, пересекающих внешнюю границу Европейского Союза, путем выдачи разрешений на въезд. Авторы этого нового масштабного проекта ясно дают понять, что разрешение ETIAS не является визой, тем не менее, эта очередная электронная система авторизации въезда улучшит управление мобильностью граждан 62 третьих стран, то есть населения численностью 1,4 миллиарда человек, имеющих право безвизового доступа к внешним границам ЕС. В настоящей статье сравниваются шенгенские визы и разрешения на въезд, которые будут введены в соответствии с регламентом ETIAS в 2022 году. Сравнительный анализ содержит ряд аргументов, подтверждающих тезис о том, что разрешения, выдаваемые в рамках нового режима ETIAS, вписываются в широкое юридическое определение визы, понимаемой как разрешение на въезд на территорию ЕС.

Ключевые слова: ETIAS, шенгенская виза, интегрированное управление границами EC, визовая политика ЕС 


\section{Introduction}

The main objective of this article is to compare Schengen visas and travel permits issued under the European Travel Information and Authorization System (ETIAS) with particular emphasis on the legal nature of the latter. In the first part of the publication, the definition of visas, their functions and the legal dimension of EU visa policy is provided to build a solid theoretical framework. Based on theoretical analysis, the paper proceeds to assess the systems of electronic entry permits implemented by Australia, the United States and Canada. Secondly, the article investigates the legal nature of ETIAS, formulating a comparative analysis of ETIAS authorization and Schengen visa as the main instruments dedicated to the control of cross-border flows of people, applied or to be implemented at the level of the European Union. In the last section, based on the findings of a field study carried out for the purpose of the paper, a conclusion is given.

The research problem addressed in the article is of growing importance, mostly due to increasing migration flows and the complex situation of the European Union in this regard. Moreover, the literature devoted to the ETIAS system, which is just being implemented and its status within the framework of the EU policy on entry permits is still limited. The starting point of the presented analyses is a hypothesis on the ambiguity of the definition of visas as a fundamental instrument for controlling the movement of people in the modern world. To verify the hypothesis, different definitions, scopes and connotations of meaning ascribed to visas are examined, including the doctrine, national and international law. Against this background, a legal definition of Schengen visas, perceived as a mechanism for preselecting third-country nationals (TCNs) entering the territory of the EU member, is presented. These findings are particularly useful to explore the legal nature and actual meaning of travel authorization issued under the new ETIAS regime. Another research hypothesis adopted in the paper is that while formally the ETIAS permit is not a visa, it fits to broad definition of visas perceived as a form or method of authorizing the entry of TCNs to EU territory. The methodology used for the purpose of the paper is rooted in European Studies and combines legal analysis with comparative politics, which allows for effective comparison of various regimes of mobility implemented by the European Union. The national, international and EU regulations as well as an extensive literature review formed the key sources for the conclusions drawn in this article, including official documents about ETIAS, Schengen visas and other currently practiced electronic entry systems. 


\section{The concept and legal nature of visas}

An examination of an ETIAS decision as an official authorization added to a passport, which permits TCNs entry into and travel within EU, requires some preliminary remarks on the legal nature of visas and the contemporary visa systems. In principle, a visa is a tool used by states to control the access of particular categories of travelers to their territory. In this sense, the term mostly refers to a permit granted to foreigners by diplomatic or consular representations of a foreign state to cross its border or stay on its territory. ${ }^{1}$ Allowing for facilitation or prevention of the mobility of certain categories of individuals, visas are specifically aimed at controlling admission at the stage of pre-departure and constitute one of the essential requirements for entry under domestic regulations. Although visas are considered a key instrument practiced by states to maintain control over the level of openness of their territories, few national legislators have decided to explain the term through a legal definition. The more precise concept of a visa was developed mainly within diplomatic practice and consular law, where it is referred to as a permit issued to foreigners by a state authority, which entitles them to enter, transit through, stay in and leave that state. This official authorization of entry includes a stamp in the passport by the competent state authority, who may refuse to issue a visa to the foreigner and revoke the already issued visa. ${ }^{2}$ Thus, in consular law and practice, a visa is considered "a stamp or other endorsement in a passport confirming the holder's right to enter or stay in the country granting the visa."

It should be noted that, as official endorsement on a passport or other document required to secure an alien's admission to the territory of a state, a visa may manifest itself physically (in the form of a document) or in the procedural dimension (a visa interpreted as a process). A dynamic approach to visas, based on defining the phenomenon in procedural terms, i.e., primarily as an administrative act, was typical for the early European Communities; however, this issue was originally not addressed in primary or secondary EC law due to the intergovernmental method of regulation practiced. ${ }^{4}$ The first elements constituting the contemporary legal construction of vi-

1 A. Meloni, Visa Policy within the European Union Structure, Berlin-Heidelberg 2006, p. 39; E. Guild, Security and Migration in the 21st Century, Cambridge 2009, p. 118; E. Guild, Moving the Borders of Europe, https://cmr.jur.ru.nl/cmr/docs/oratie.eg.pdf [access: 1.03.2021]; S. Mau, H. Brabandt, L. Laube, Ch. Roos, Liberal States and the Freedom of Movement. Selective Borders, Unequal Mobility, London 2012, p. 54.

2 B. Dobrzańska, M. Sitek, Mini leksykon dyplomatyczny, Józefów 2011, p. 64; A. Meloni, Visa Policy..., p. 32.

3 L.T. Lee, J.B. Quigley, Consular Law and Practice, Oxford 2008, p. 234.

4 M. Cesarz, Communitarian and Intergovernmental Dimension of EU Visa Law, Review of European and Comparative Law 2019, vol. 37, no. 2, pp. 7-31. 
sas were outlined by the Court of Justice in its case-law: in 1979, the court ruled that "an entry visa or equivalent requirement" covers any formality for the purpose of granting leave to enter the territory of a member-State which is coupled with a passport or identity card check at the frontier, whatever may be the place or time at which that leave is granted and in whatever form it may be granted."

Significantly, although the Schengen Agreement and the Convention implementing the Schengen Agreement did address the issue of visas, they did not specify the meaning of the term. The legal definition was established in 1995 by a regulation listing the countries whose citizens were required to hold a visa when crossing the external borders of the Member States and it has not changed much since then. ${ }^{6}$ Therefore, for the purposes of the currently binding Common Code on Visas (Visa Code), a visa is defined as an authorization issued by a Member State with a view to an intended stay on the territory of the Member States not exceeding 90 days in any 180-day period or transit through the international transit areas of airports of the Member States. ${ }^{7}$

\section{Visas in international and domestic law}

Visa and passport policies significantly facilitate the exercise of states' sovereign powers to administer cross-border movement of persons and control access to their own territory. Selective border control has also been a primary motivation for the proliferation of visas and similar permits: states use visa restrictions to maintain the balance between facilitating entry into their own territory for citizens from certain countries (mostly for economic and political reasons) and impeding it for those from other countries who pose a security threat. ${ }^{8}$ The concept of the states monopoly to control the crossing of their borders by persons who are not their nationals is well established in public international law and has been accepted by the European Court of Human Rights (ECHR), which has confirmed the competence of national

5 Judgment of the Court of 3 July 1980, Regina v. Stanislaus Pieck, C 157/79, ECLI:EU:C:1980:179.

6 Council Regulation (EC) No 539/2001 of 15 March 2001 listing the third countries whose nationals must be in possession of visas when crossing the external borders and those whose nationals are exempt from that requirement, OJ L 81, 21.03.2001, pp. 1-7.

7 Article 2, points 2 (a) and 2 (b) Regulation (EC) No 810/2009 of the European Parliament and of the Council of 13 July 2009 establishing a Community Code on Visas (Visa Code), OJ L 243, 15.09.2009.

8 M. Cesarz, Polityka wizowa Unii Europejskiej jako metoda kontroli przekraczania granic, in: Unia Europejska w poszukiwaniu swoich granic, ed. M. Trojanowska-Strzęboszewska, Warszawa 2017, pp. 65-89. 
authorities to control the entry of foreigners. ${ }^{9}$ Since there is no general norm of international law granting the admission of foreigners into the territory of a state, if international agreements do not provide otherwise, states regulate the movement of persons and goods across their borders on their own. ${ }^{10}$ The permits mentioned constitute an integral part of the domestic regulations addressing legal status of foreigners, which remains a sovereign right of national governments executed within the framework of administrative law. The refusal or issuance of visas is therefore a state's own competence unless the international obligations of the state concerned impose limits in that matter. ${ }^{11}$

At the level of national law, a visa is a form of an administrative act or, more precisely, a decision with a specific name granting permission to enter the territory of a state. Since the law provides for the obligation to obtain an official authorization before performing a certain action or undertaking an activity (in this case, entry into the territory of the state), regardless of the name given, it should be regarded a permit. The issuance or refusal of a visa takes place in the form of a decision taken based on regulations listing detailed requirements for the granting or denial of entry (the latter in immigration law terms known as the grounds of inadmissibility).

Therefore, the essence of this form of authorization is to issue "a binding confirmation, that - based on the applicable law - there is no sufficient obstacle to undertake a particular activity" which, in the situation discussed, is entry into the territory of the country granting the visa. Thus, visa procedures leave the authorized body a large scope of freedom by referring to vague notions (such as state security, security of international relations, etc.).

The fact that the states values or interests protected or pursued in this way are not defined indicates that this is left to the discretionary decision of the authorized institution, which allows visas to be classified as "discretionary permits". This makes it possible to determine the scope of an individual's negative subjective rights in relation to the entity exercising public authority, or to determine the limits of their positive rights. ${ }^{12}$ However, the authorized visa body is always obliged to provide an applicable legal provision from which the conclusion can be drawn as to the

9 Judgement of European Court of Human Rights of 18 February 1991, Moustaquim v. Belgium, application no. 12313/86, https://www.equalrightstrust.org/ertdocumentbank/Moustaquim\%20v\%20 Belgium\%20_authorities\%20abuse_pdf [access: 1.03.2021].

10 E. Dynia, Ewolucja polityki migracyjnej Unii Europejskiej - wnioski de lege ferenda, in: W obliczu kryzysu. Przyszłość polityki azylowej i migracyjnej Unii Europejskiej, ed. A.M. Kosińska, Lublin 2017, p. 10.

11 Administracyjnoprawny status jednostki (wybrane zagadnienia), ed. M. Stych, Częstochowa 2012, p. 142.

12 A. Modrzejewski, Charakter prawny wiz jednolitych krótkoterminowych w Unii Europejskiej, in: Status prawny cudzoziemca w Polsce, ed. M. Zdanowicz, Białystok 2007, p. 92. 
inadmissibility of the conduct for which it intends to withhold permission. In conclusion, the evaluation of a foreigner's conduct is materialized in the legal form of entry permit and is pursued based on premises that are formulated by the visa authority itself but limited by the obligation to fit within the framework set by the applicable law. ${ }^{13}$

When analyzing the legal dimension of visas, it is also necessary to refer to the rights of the persons to whom the permit is issued. Acquisition of a visa is not equivalent to an absolute right of entry: whether an alien will be allowed to cross the border depends not so much on whether a person is in possession of a valid visa (and other required documents) as on whether the conditions which enabled to obtain the visa, and which are verified again at the border crossing, are met. ${ }^{14}$ More precisely, an automatic right of entry is not granted by a visa-free regime either, because the border services still retain the right to refuse entry, although such cases are relatively rare. ${ }^{15}$ Although the scope of rights acquired by the visa holder is, in principle, interpreted by the national authority, the doctrine sometimes classifies the visa as a transnational administrative act. This stems from the view that the issuance of such permits is a symbolic expression of the state's right to control the entry of foreigners, while the visas themselves are an important instrument of foreign policy and an emanation of the objectives of the state's internal policy, as well as a function of international relations and internal security. In this view, the granting of a visa remains a measure of international character insofar as it has effects in other national legal systems. ${ }^{16}$

Judicial review of visa decisions is another important issue, particularly for applicants. As mentioned, there is no subjective right to a visa under international law, but one can assume that there is a right to a fair and correct examination of a visa application. In accordance with the principle of transparency and equality, visa authorities have a duty to provide for the reasons for visa refusal. More importantly, national legislation should also include the right of appeal against negative visa decisions. In most liberal democracies, it is recognized as a constitutional right of the individual, as it secures protection against arbitrariness and allows for the judicial

\footnotetext{
13 Ibidem.

14 Ibidem, p. 93.

15 In fact, cases of travelers being denied entry at the border who have obtained, for example, a visa to the United States are relatively rare. Cf. J.A. Gilboy, Deciding Who Gets in: Decision Making by Immigration Inspectors, Law \& Society Review 1991, vol. 25, no. 3, pp. 574-575.

16 A. Modrzejewski, Charakter prawny..., pp. 96-97.
} 
review of executive power. ${ }^{17}$ However, the parties involved in visa proceedings are not the citizens of the issuing country but foreigners, hence the visa laws of most countries in the world do not fully respect such principles. Even if a judicial review of the procedure is available, in many cases the competent authorities are generally not required to give reasons for rejecting a visa application. Additionally, the right of appeal itself, even if provided for by national law, may be of administrative, judicial, or mixed character, and may involve some hybrid legal institutions that fall between administrative and judicial review.

\section{Traditional visas vs E-visas}

In the strict legal sense, a visa is an authorization issued by the state to cross its borders, embodied in the form of a vignette in the passport, travel title or other valid document, allowing the person to cross the border. ${ }^{18}$ The formal expression of the granting of a visa is an endorsement made in a passport or other travel document; however, it is necessary to distinguish between a visa as an administrative decision and the affixing of a completed visa sticker in a passport or other travel document. ${ }^{19}$ The very act of issuing a visa has the features of an administrative decision in the material and legal sense; affixing a visa sticker, on the other hand, is merely a material and technical act and does not determine the legal situation of an individual because it must be preceded by a decision of a given authority as to whether, in a given situation, the applicant meets all the entry requirements stipulated by law. ${ }^{20}$

At present, there is a growing number of electronic visas (Electronic visa/e-Visa/ eVisa) in circulation, issued mainly via the Internet and then stored in the computer system of the issuing country and assigned to a particular passport. This type of entry permit is not expressed in the form of a visa sticker in the passport: applicants receive a visa electronically after entering the required data and making a payment, then passport control services at border crossings verify the e-visa in the electronic registry. In this case, the boundary between issuing a visa decision (administrative decision) and issuing a visa document becomes blurred, as the authorization takes an intangible form (instead of a stamp or sticker added to the passport). Applying

\footnotetext{
17 H. Brabandt, S. Mau, Liberal Cosmopolitanism and Cross-Border Mobility: The Case of Visa Policies, Global Society 2013, vol. 27, no. 1, p. 69.

18 A. Modrzejewski, Charakter prawny..., p. 99.

19 Administracyjnoprawny status jednostki..., p. 142.

20 A. Modrzejewski, Charakter prawny..., p. 99.
} 
for a e-visa usually does not require direct contact with the consulate or embassy of the country granting the visa. Thus, the application procedure is simpler, faster and is limited to filling out the form on the website (usually 2-3 days in advance of travel) and receiving a confirmation by e-mail.

Due to their intangible form and liberalized application process, e-visas are an intermediate form of official permit, located between visa and visa-free travel. At present, many countries have introduced or developed e-visas (or other similar entry permits), ${ }^{21}$ but complex systems based on such forms of electronic verification of the right of entry have primarily been established by the United States and Australia. ${ }^{22}$ The latter was the first to introduce electronic permits mentioned and since 2015 has ceased issuing traditional visas in the form of a passport sticker, while implementing numerous programs to simplify entry authorization procedures. For instance, eVisitor program (subclass 600) allows applicants to apply for electronic tourist or business visas for stays of up to 12 months. Citizens of most countries in the world can apply online for the visa concerned, and the expected processing application time is from 2 to 46 days, depending on the type of permit and additional information about the applicant required (in some cases, the application will be processed additionally by an officer of the relevant service). The cost of issuing a visa ranges from 145 to 1,065 Australian dollars. ${ }^{23}$

\section{Visas and Electronic Travel Authorization (ETA) Systems}

A discussion on the legal dimension of visas would be incomplete without addressing the difference between eVisas and similar Electronic Travel Authorisation (ETA) systems, which are increasingly being used in the world for the efficient

21 These include inter alia Armenia, Australia, Azerbaijan, Bahrain, Brazil, Canada, Ethiopia, Georgia, India, Kenya, Kuwait, New Zealand, Rwanda, Singapore, Sri Lanka, Turkey, U.S.A., Vietnam.

22 M.B. Salter, C.E. Mutlu, The 'Next Generation' Visa. Belt and Braces or the Emperor's New Clothes? Implications for the EU'S Migration and Asylum Policies, CEPS Paper in Liberty and Security in Europe 2011, http://aei.pitt.edu/32548/2/No_44_Salter_Mutlu_on_next_generation_visas_final.pdf [access: 1.03.2021].

23 A variant of the program is eVisitor (subclass 651), introduced in 2008 under visa reciprocity agreements with the EU to simplify procedures for short-term stays. The eVisitor permit is available to citizens of 28 Member States of the European Union and 8 other European countries that have joined the Schengen area. The permit is issued for free and entitles to a 3-month stay in Australia for family, tourist or business purposes. $90 \%$ of applications are processed within 2 days, see: Australian Government, Department of Home Affairs, Immigration and citizenship, https://immi.homeaffairs.gov.au [access: 1.03.2021]. 
management of borders and movement of persons. Electronic Travel Authorization (ETA) is mostly used for visa-exempt individuals also offering the possibility to continue applying for the correct visa in case of ETA refusal. Australia, Canada, Hong Kong, India, Sri Lanka and the U.S. are currently word leaders in use of such permits, although the authorities and immigration laws of the countries discussed do not formally classify entry authorizations obtained this way as visas, despite their having a similar function.

The most developed system of this type is the United States' online Electronic System for Travel Authorization (ESTA), which functions as a form of pre-screening of travelers for security purposes and does not qualify as a visa under U.S. immigration law. The program covers all passengers participating in the Visa Waiver Program (VWP), which offers visa-free travel to citizens of approximately 38 countries. It requires electronic registration at least 72 hours prior to entering the U.S., with an ESTA authorization application only required when crossing U.S. borders by sea or air (but no longer by land). This authorization does not guarantee entry into the USA, as the final decision is taken by the U.S. Customs and Border Protection Agency. ${ }^{24}$

The Australian ETA ${ }^{25}$ scheme, on the other hand, is available to citizens of 34 visa-free countries visiting Australia for tourism or business purposes. The authorization allows for multiple entries into Australia during a 12-month period, allowing a stay of up to 3 months each time. Eligible travelers can apply for the authorization using a simple online form and it is free of charge (although an application processing cost of 20 Australian dollars is charged). It is worth mentioning that the Australian regime defines the ETA as a type of short-term visa (placing it in the Visitor visas class along with the eVisitor program discussed earlier), although the permit is actually a form of visa-free travel. ${ }^{26}$ Additionally, Canada requires all travelers arriving by air under visa waiver (except U.S. citizens) to apply for an electronic travel authorization (eTA) prior to arrival. The eTA is electronically linked to the traveller's passport and is valid for up to 5 years, allowing for short stays of no more than 6 months at a time. As in the case of visas, the final decision on entry is always made by the Canada Border Services Agency. ${ }^{27}$ ETA applications are submitted online and require filling out a simple form, with most applicants receiving

24 U.S. Customs and Border Protection, https://esta.cbp.dhs.gov/esta/ [access: 1.03.2021].

25 Electronic Travel Authorisation (subclass 601).

26 Australian Government, Department of Home Affairs, Immigration and citizenship, https://immi. homeaffairs.gov.au/visas/getting-a-visa/visa-listing [access: 1.03.2021].

27 Goverment of Canada, Find out about Electronic Travel Authorization (eTA), https://www.canada.ca/ en/immigration-refugees-citizenship/services/visit-canada/eta/facts.html [access: 1.03.2021]. 
confirmation by email within minutes. However, some applications may take several days to process if additional documents are required. The cost of an eTA is 7 Australian dollars. ${ }^{28}$

\section{ETIAS as an EU ETA-type system}

The idea behind the ETIAS proposal comes directly from the U.S., where, as mentioned, a similar system (ESTA), has already been in place since $2009 .{ }^{29}$ At the EU level, it originally emerged in 2008, alongside other proposals for modernizing the EU border management system, in particular the setting up of an Entry/Exit System (EES) and a Registered Traveller Programme (RTP)..$^{30}$ The more detailed vision of the ETIAS project dates back to 2013, when the concept of the EU Smart Borders was developed. However, motivated by the increase in migration flows in 2015 and the need for increased security following the attacks in Belgium and France, on 16 November 2016, the European Commission presented a revised draft of regulations establishing the European Travel Information and Authorisation System (ETIAS). ${ }^{31}$ Consequently, on 25 April 2018, the agreement between the Council Presidency and the European Parliament, on this new EU large-scale data system collecting data of visa-exempt travelers from third countries, was eventually confirmed.

According to EU institutions and regulations, ETIAS authorization is not a visa. ${ }^{32}$ Generally, the new solution is designed to allow for advance checks and, if necessary, deny travel authorization to visa exempt TCNs travelling to the Schengen area. The system will improve internal security, prevent illegal immigration,

28 Ibidem.

29 N. Vavoula, European Travel Information and Authorisation System (ETIAS): A Flanking Measure of the EU's Visa Policy with Far Reaching Privacy Implications, Queen Mary School of Law Legal Studies Research Paper 2017, no. 256, p. 2, https://papers.ssrn.com/sol3/papers.cfm?abstract_id=2928082 [access: 1.03.2021].

30 Ibidem.

31 Proposal for a Regulation of the European Parliament and of the Council establishing a European Travel Information and Authorisation System (ETIAS) and amending Regulations (EU) No 515/2014, (EU) 2016/399, (EU) 2016/794 and (EU) 2016/1624, COM/2016/731 final - 2016/0357 (COD), Brussels, 16.11.2016, https:// eur-lex.europa.eu/legal-content/EN/TXT/?uri=COM:2016:731:FIN [access: 1.03.2021].

32 Article 2.9 of Opinion of the European Economic and Social Committee on the 'Proposal for a Regulation of the European Parliament and of the Council establishing a European Travel Information and Authorisation System (ETIAS) and amending Regulations (EU) No 515/2014, (EU) 2016/399, (EU) 2016/794 and (EU) 2016/1624, COM/2016/731 final, OJ C 246, 28.07.2017, pp. 28-33. 
protect public health and reduce delays at the borders by identifying persons who may pose a risk in one of these areas before they arrive at the external borders. ${ }^{33} \mathrm{Fast}$ and effective immigration control is not the sole purpose of ETIAS: unsurprisingly, the new database will be used in order to assist in the fight against terrorism and other serious crimes under conditions which are very similar to those prescribed in the Eurodac system. ${ }^{34}$ Since the purpose of the paper is to highlight the similarities and differences between ETIAS and other forms of entry permits, the principles and technical aspects of the system itself are not discussed in detail. Considering the previously presented typology, ETIAS fits into the category of modern, technically highly developed systems of electronic travel authorization (ETA) already used by a number of countries in the world. Thus, the following part of the publication contains a comparative analysis of this new large-scale travel authorization system and the already functioning Schengen visas.

The personal scope of the adopted ETIAS regulation covers TCNs listed in Annex II to Council Regulation (EC) No 539/2001 (6) who are exempt from the visa requirement for an intended stay in the territory of the Member States of a duration of no more than 90 days in any 180-day period (and thus included in the so-called 'positive or white visa list'). ${ }^{35}$ The approach adopted by the EU implies that the ETIAS system will be also applied to visa-exempt TCNs, including family members of EU citizens and TCNs enjoying the right of free movement who do not hold a residence permit. ${ }^{36}$ As an electronic entry authorization system linked to the traveller's passport, it regulates the movement across external borders of nationals from 62 third countries (such as the U.S., Australia or New Zealand) who currently do not need any authorization or visa in any form to enter the EU. This means that the system will apply to a population of around 1,4 billion people who are

33 European Travel Information and Authorisation System (ETIAS): Council Confirms Agreement with European Parliament, https://www.consilium.europa.eu/pl/press/press-releases/2018/04/25/european-travel-information-and-authorisation-system-etias-council-confirms-agreement-with-european-parliament/ [access: 1.03.2021].

34 N. Vavoula, European Travel Information..., p. 4.

35 Article 2 (1) (a) of Regulation (EU) 2018/1240 of the European Parliament and of the Council of 12 September 2018 establishing a European Travel Information and Authorisation System (ETIAS) and amending Regulations (EU) No 1077/2011, (EU) No 515/2014, (EU) 2016/399, (EU) 2016/1624 and (EU) 2017/2226, OJ L 236, 19.09.2018, pp. 1-71 (hereinafter: the ETIAS Regulation).

36 The right to a travel permit is not unconditional, as family members who pose a risk to public order, public security or public health may be denied a permit. However, the scheme will not apply to EU citizens or holders of long-stay visas, holders of local border traffic permits, nationals of micro-states in the Schengen area, as well as holders of diplomatic passports and members of the crew of ships or aircrafts on duty, cf. Article 2 (2) of ETIAS Regulation. 
eligible for visa-free travel and whose inflow into the EU is constantly increasing. ${ }^{37}$ Thus, the new European ETA-type regime applies to a different category of TCNs than the Schengen visas, which are required for nationals of countries on the socalled "black" (negative) visa list, currently covering $80 \%$ of the world's population.

Furthermore, the territorial scope of the entry permits compared does not overlap. A positive visa decision allows TCNs requiring a visa to travel within the territory of the 26 Schengen countries. However, not all EU Member States belong to the Schengen zone (including Ireland, Romania, Bulgaria, Croatia and Cyprus); on the other hand, the Schengen acquis - including the principles of EU visa policy - is also applied by countries that are not members of the European Union (Norway, Iceland, Switzerland and Liechtenstein). Moreover, in practice, there are several types of Schengen visas, and some of them are valid only for the territory of one or several countries of the zone. ${ }^{38}$ In principle, ETIAS allows for travel within the entire European Union, but also provides for the possibility of issuing a travel authorization with limited territorial validity. ${ }^{39}$

It should be noted that the creation of ETIAS reflects the growing trend towards the digitalization of border controls ${ }^{40}$ which assumes virtual processing of applications. The information contained within each application is automatically cross-checked against EU and relevant Interpol databases to determine whether there are grounds for refusing to issue a travel authorization. If there is "no hit" in the system, the authorization is to be issued quickly and automatically (i.e., within minutes). This is estimated to be the case for $98-99 \%$ of applications submitted, but if an element requiring analysis appears, the application should be examined on a case-by-case basis. The ETIAS Central Unit will first check if the data recorded in the application dossier matches the data justifying the hit and, if this is the case, to be examined individually by the ETIAS National Unit of the responsible Member State. ${ }^{41}$ The decision to authorize or deny a request that has resulted in a hit will be taken no later than 96 hours after submission or, if additional information is requested, within 96 hours of receipt of that information. ${ }^{42}$

\footnotetext{
37 Proposal for a Regulation of the European Parliament...

38 In addition to the issuance of 'uniform visas' valid for the entire territory of the Member States; the Visa Code allows for the use of so-called 'visas with limited territorial validity', cf. Visa Code, Article 2 (4).

39 ETIAS Regulation, Article 44.

$40 \quad$ Fall 2018 - ETIAS and Schengen Area Updates, https://etias.com/articles/fall-2018-etias-and-schengen-area-updates [access: 1.03.2021].

41 A New Travel Authorisation for EU Visitors, https://etias.com [access: 1.03.2021].

42 ETIAS Regulation, Article 30.
} 
Unlike the fully digitalized ETIAS permit, the Schengen visa is still inserted manually into a passport in the form of a sticker. The affixing of the visa sticker in the passport is a substantive technical operation, preceded by a decision by the national authority, which determines by means of an administrative decision whether the applicant fulfils all the entry requirements laid down by law. ETIAS authorization, on the other hand, is centralized at EU level and totally dematerialized. In addition, the permit is valid for three years (and allows for an unlimited number of entries $)^{43}$ and thus much longer than the short-stay visas issued by the Schengen states, which entitle their holders to travel within each of the 26 Schengen states for up to 90 days in each 180-day period. The cost of ETIAS travel authorization is also much more favourable, as the fee is set at $€ 7$, like the Canadian eTA. The cost of obtaining a Schengen visa is comparably higher and amounts to $€ 80$.

While the conditions and procedures for issuing Schengen visas are harmonized, the decision to issue visa concerned still belongs the national authorities. The applications must, in principle, be lodged in person at the embassy or consulate of the country of destination: this often appears problematic for applicants deprived of access to these facilities in their country of origin, and outsourcing does not always provide a remedy to the problems of accessibility to visa services, especially as it increases the final cost of obtaining the visa document. After verifying the admissibility of the application, the authorized national authority enters an alert in the Visa Information System (VIS). The next step in the procedure is to verify if the applicant fulfils the entry conditions as set out in the Schengen Borders Code, i.e. that he does not represent a risk of illegal immigration or pose a threat to the security of the member state and that he intends to leave the territory of the member state before the expiry of the visa he applied for.$^{44}$ In this context, the determinants of the entry authorization policy as set out in the ETIAS Regulation are less developed: applications are processed for the purpose of assessing whether the applicant's entry into the Union poses a security risk, a risk of illegal immigration or a high epidemiological risk within the Union. ${ }^{45}$

As the process for issuing Schengen visas is not yet fully automated, the applications shall be decided on within 15 calendar days of the date of the lodging of an admissible application with possible extension of the period up to 30 calendar days in individual cases, notably when further scrutiny of the application is needed. ${ }^{46} \mathrm{In}$ practice, many Schengen countries experience problems in meeting the deadlines

\footnotetext{
43 ETIAS Regulation, Article 36 (5).

44 M. Cesarz, Polityka wizowa..., p. 72.

45 ETIAS Regulation, Preamble, $\$ 22$.

46 Visa Code, Article 23 (1) and (2).
} 
set by EU visa law. On the other hand, the application for ETIAS is filled out online, which eliminates the obligation to go to the consulate and the filling out of the application itself, which, due to fewer formal requirements, takes from a few to several minutes ${ }^{47}$ In exceptional circumstances, when serious doubts about the information or documents submitted by the applicant persist, the ETIAS national unit of the responsible member state may invite the applicant for an interview in his/her country of residence at its nearest consulate or at a consulate located in a country other than the applicant's country of residence. ${ }^{48}$ However, ETIAS travel authorization does not reintroduce the formalities of the Schengen visa application as the new large scale system (unlike the VIS) does not collect biometric data and stores much less information compared to other EU large-scale databases. However, as with visas, the ETIAS design reflects a trend towards the extraterritorialization and privatization of border controls, with the burden of numerous obligations placed on air and sea carriers: the carriers are required to verify that TCNs hold a valid ETIAS permit before passengers board. ${ }^{49}$

Regarding the right to appeal against a refusal of entry it should be noted, that in the case of a negative visa decision, the appeal procedure is conducted against the member state that has taken the final decision on the application and in accordance with its domestic law, and national authorities are obliged to provide the applicants with information on the available procedural measures. ${ }^{50}$ Furthermore, the Court of Justice of the EU also confirmed that visa procedures are subject to judicial review (including the one performed by the CJEU). In the Koushkaki case, the court also agreed with the ECHR's thesis that there is no subjective right to a visa; member states do not have a duty to issue entry permits, which is obvious from the perspective of international law, recognizing visa issuance as a discretionary power of a sovereign member state. ${ }^{51} \mathrm{EU}$ members also enjoy a relatively large scope of discretion when it comes to defining requirements/conditions for issuing

47 The form requires basic personal information, but also details of the last conflict countries visited and information about the applicant's criminal record, and the first destination country of the EU visit must be specified.

48 ETIAS Regulation, Article 27 (4).

49 International carriers transporting groups by road in coaches will also be subject to this obligation 3 years after the system becomes operational. ETIAS Regulation, Article 45 (9).

50 Visa Code, Article 32 (3). These provisions apply accordingly to persons whose visas have been cancelled or revoked.

51 Judgment of the Court of 19 December 2013, Rahmanian Koushkaki vs. Germany, C 84/12, ECLI:EU:C:2013:862. 
a uniform visa, including the grounds for inadmissibility set out in EU law; however, if those grounds are not present, the visa should be granted. ${ }^{52}$

A member state is therefore required to issue a visa document to individuals who have proved beyond reasonable doubt that they meet the entry conditions laid down in the Schengen Borders Code or who should be exempt from that visa requirement under provisions relating to asylum and international protection. ${ }^{53}$ In the 'Hassani' case, the CJEU ruled that supervision over the conduct of visa procedures is exercised by the courts of the member state concerned. The ruling stipulates that it is for each member state to determine the nature of the appeal against a decision to refuse a visa, provided that the means of redress chosen by it do not undermine the principles of equivalence and effectiveness. However, the national procedure must guarantee at a certain stage of the proceedings a remedy before a court. ${ }^{54}$

The ETIAS Regulation also introduced the right to appeal for applicants who have been denied a travel permit. In legal terms, the ETIAS travel authorization is a decision issued in accordance with the provisions of Regulation 2018/1240, confirming that TCNs meet the conditions for entry into the territory of the European Union. ${ }^{55}$ In particular, it is a validation that there are no reasons to consider the presence of the person in the territory of the member state poses a security risk, a risk of illegal immigration or a high epidemiological risk. In the event of a negative decision, the appeals procedure works similarly to the one applied in case of Schengen visas: the appeals procedure shall be conducted in the member state which decided on the application and in accordance with its law. The ETIAS national unit of the responsible member state shall also provide applicants with information on the appeal procedure in one of the official languages of the state of which the applicant is a national. ${ }^{56}$

It is worth noting that a permit that has already been issued should be annulled or revoked if it turns out that the conditions for issuing the travel authorization were not or are no longer met, which brings ETIAS closer to the EU visa regime. The annulment or revocation of a Schengen visa is conducted by the issuing state and - in the case of ETIAS authorization - by the national unit of the member

52 The visa authorities of a Member State may only refuse to issue a uniform visa to an applicant if one of the grounds for refusal listed in the Visa Code can be invoked against the applicant. Cf. Judgment of the Court of 19 December 2013...

53 V. Moreno-Lax, Accessing Asylum in Europe: Extraterritorial Border Controls and Refugee Rights under EU Law, Oxford 2017, p. 97.

54 Judgment of the Court of 13 December 2017, Soufiane El Hassani vs. Minister of Foreign Affairs, C 403/16, ECLI:EU:C:2017:659.

55 ETIAS Regulation, Article 3 (1).

56 ETIAS Regulation, Article 37 (3). 
state that granted the permit. Schengen visa holders, whose visa has been annulled or revoked, shall have the right to appeal; the same applies to individuals equipped with ETIAS travel authorization. In both situations, appeals procedure is governed by national law. ${ }^{57}$ Additionally, an ETIAS permit - like Schengen visa - does not confer automatic right of entry or stay in the territories of an EU Member States since the final decision in this respect is up to border guard assigned to carry out border checks in accordance with national law. ${ }^{58}$

The comparison of the function and placement in the EU Integrated Border Management system of both entry authorization mechanisms constitutes a relevant part of the undertaken analysis. As another large-scale electronic system established by the Union in the area of migration policy and external border control, ETIAS is managed by the EU-LISA Agency. The previous systems, although not without their shortcomings, have generally proven their effectiveness as a tool for regulating visa traffic (VIS), an instrument in the fight against abuse of the law in asylum procedures (Eurodac) or crime and violation of prohibitions on entry into the Union (SIS). ${ }^{59}$ Despite the differences, these measures have a common goal: to ensure the migration security of host countries, to counter irregular immigration and to reduce the threat of terrorism. ${ }^{60}$ Therefore, another prerequisite for the effective operation of ETIAS is the interoperability with other EU information systems (SIS, VIS and Eurodac) advocated by the European Commission, with particular emphasis put on access by law enforcement authorities to data collected on third-country travelers. ${ }^{61}$ The establishment of ETIAS is mostly justified by the need to bridge gaps or to provide a link between data exchange systems at national and EU level.

From the perspective of the EU mobility regime, the new database fills the gap generated by the inflexibility of the Visa Code, which remains, however, together with the VIS, the main instrument of border control based on the selection and pre-screening of travelers. ${ }^{62}$ The specific target of ETIAS are persons who fall

57 ETIAS Regulation, Article 40 and 41; Visa Code, Article 34 (7).

58 ETIAS Regulation, Article 36 (6).

59 A.M. Kosińska, ETIAS czyli szczelne granice Unii, https://ec.europa.eu/poland/news/170201_etias_pl [access: 1.03.2021].

60 Ibidem.

61 Regulation (EU) 2019/817 of the European Parliament and of the Council of 20 May 2019 on establishing a framework for interoperability between EU information systems in the field of borders and visa and amending Regulations (EC) No 767/2008, (EU) 2016/399, (EU) 2017/2226, (EU) 2018/1240, (EU) 2018/1726 and (EU) 2018/1861 of the European Parliament and of the Council and Council Decisions 2004/512/EC and 2008/633/JHA, OJ L 135, 22.05.2019, pp. 27-84.

62 A. Meloni, EU visa Policy: What Kind of Solidarity?, Maastricht Journal of European and Comparative Law 2017, vol. 24, no. 5, p. 156. 
outside the scope of the VIS regulation and are not recorded in the VIS, ${ }^{63}$ but the very design of ETIAS will allow the maintenance of existing privileges for aliens from visa-exempt countries, while raising security standards. In a situation where it is not possible to completely waive control at the external borders, an intermediate measure was adopted, which, on the one hand, makes it possible to retain the right of entry to the European Union for foreigners from countries placed on the positive visa list and, on the other hand, provides the border services of member states with an effective tool to control migration flows. ${ }^{64}$ These objectives fall within the scope of the EU Integrated Border Management strategy, laid down in Article 77 of the TFEU, based inter alia on the continued development of legal measures on the entry and residence of TCNs in the EU, operational measures relating to the organisation of the visa, operational measures at the external borders and, in the Schengen area, the implementation of new technologies in a broad and balanced manner, consistent with EU systems for the control of the movement of persons.

Policy based on Schengen visas and ETIAS represents a nexus of conflicting imperatives for contemporary, developed, liberal members of the European Union: there are commercial and social pressures in favour of integration and movement; a security impetus to protect the population; international human rights obligations; procedural and substantive justice concerns for the recognition and the settlement of refugees; and efficiency concerns about border management. ${ }^{65} \mathrm{EU}$ members, like Canada, manage these complex pressures through visas, visa-waiver programmes and multilateral or bilateral visa agreements. ${ }^{66}$ The idea of setting up ETIAS refers also to the beneficial experiences of Australia or the United States, which had previously implemented similar measures for controlling people crossing borders.

The new solutions adopted at the EU level are an attempt to keep up with global trends in the policy of granting entry permits, motivated by migration pressure and terrorist threats. In the case of the EU, however, the main reason for the introduction of the large-scale systems was the abolition of internal border controls: for example, the creation of Eurodac was linked to the need to establish transparent rules for processing applications for international protection. ${ }^{67}$ This was also the reason for creating the VIS, which is intended to help implement a common visa policy by

\footnotetext{
63 Ibidem, p. 157.

64 A.M. Kosińska, ETIAS czyli szczelne granice Unii...

65 M.B. Salter, C.E. Mutlu, The 'Next Generation' Visa..., p. 1.

66 Ibidem.

67 B. Kuster, V.S. Tsianos, How to Liquefy a Body on the Move: Eurodac and the Making of the European Digital Border, in: EU Borders and Shifting Internal Security, Technology, Externalization and Accountability, eds. R. Bossong, H. Carrapico, Cham 2016, p. 45.
} 
simplifying the processing of visa applications and the control of external borders, while at the same time contributing to preventing threats to the internal security of the member states. ${ }^{68}$ As a result, new systems, such as ETIAS and EES (Entry-Exit System), have the function of "pre-screening travelers": they are not meant to deal with what happens at the external borders of the EU, but rather with what happens before the border is crossed, and, in combination with VIS and SIS II, they form a 'pre-screening' and border-crossing system, targeting all foreigners entering the EU.

\section{Conclusion}

The comparative analysis of Schengen visas and ETIAS travel authorization has revealed similarities between the two forms of entry permits established at the European Union level. In legal terms, both measures are strictly linked to the traveller's passport and classified as decisions issued in accordance with the provisions of Union law that confirm admissibility of TCNs to EU territory or the Schengen area. As a sui generis type of authorization, they constitute one of the pillars of the EU Integrated Border Management system, aimed to regulate the movement of across external borders; however, the personal and territorial scope of the measures compared is not the same. ETIAS authorization is characterized by a higher degree of digitalization and simplification of the application process, which brings it closer to other ETA-type electronic traveller authorization systems. The decision-making process seems to be more centralized as well, since the processing of an application is the sole responsibility of the ETIAS Central Unit, and only in case of doubt is the application handled individually by the ETIAS National Unit. Contrary to ETIAS, uniform visas are always issued by the national authorities of the member state. It should be noted that the validity of an ETIAS permit is also longer than that of a Schengen visa, and the fee charged is relatively low compared with the cost of acquisition of the visa document.

At present, the requirements for TCNs entering EU are dependent on the purpose of their trip: travel authorization may be secured via the Schengen visa procedure and through ETIAS for visa-exempt individuals if the trip concerns a short stay, or via a national long-stay visa procedure for other purposes. These procedures,

68 S. Zawadzka, System wjazdu i wyjazdu (EES) i Europejski system informacji o podróży oraz zezwoleń na podróż(ETIAS). Rola i znaczenie nowoczesnych systemów w zakresie działań prewencyjnych $i$ wzmacniania bezpieczeństwa UE, Bezpieczeństwo. Teoria i Praktyka 2019, no. 4, p. 111. 
in particular the Schengen visa procedure for short stays, amount to migration enforcement and in some cases (e.g., screening of travel authorization applications for public order motives) to a law enforcement practice as well. ${ }^{69} \mathrm{In}$ formal terms, ETIAS travel authorisation is distinct from a visa and will not require more information or be more burdensome for the applicant than a visa. Therefore, the EU legislator does not classify the new entry authorization as a visa, although the ETIAS permit meets the conditions forming the broad definition of entry visas adopted at the level of consular law and CJEU case law.

Recognizing visas as a set of formalities associated with an application for an official permit to enter the territory of a member state and connected with passport control at the border, regardless of the time, place and form, should qualify ETIAS as a simplified form of eVisa. Being a measure used for the purpose of 'pre-screening' travelers and increasing the efficiency of border management, ETIAS features a lower degree of complexity, suitable for the selection of TCNs entering the EU and formally covered by the visa-free regime. Application of ETIAS provides a potentially effective tool of policing, which - like Schengen visas - divides the applicants into two categories: legitimate, trustworthy travelers and travelers with unclear intentions. The restrictive policy of ETIAS is borne out of the securitization of foreigners and reflects the same EU rationale aimed to limit TCNs mobility. Compensating for the shortcomings of the VIS, the new system may provide an effective remedy for maintaining visa-free travel in line with EU security standards. This seems to be confirmed by the experience of Australia, Canada and the U.S. with successful ETA-type systems. According to the analysis presented, EU legislators have likely borrowed solutions directly from the Visa Code. This applies to the appeal procedure and the lack of an automatic right to cross the EU external border for both Schengen visa and ETIAS permit holders. Furthermore, the two examined systems do not establish a subjective right to a visa or authorization to enter the territory of the EU member. They are also based on the extraterritorialization and privatization of the verification of entry permits, which is reflected in the assignment of responsibilities in this area to air and sea carriers. Thus, the concept of ETIAS travel authorization results from both the relatively new experience of countries that have already implemented ETA systems and the existing 'acquis' and EU practice in issuing Schengen visas.

69 Operational Practices of EU Entry Governance at Air, Land and Sea Borders, ed. J. Jeandesboz, ADMIGOV, Brussels 2020, p. 54, https://admigov.eu/upload/Deliverable_D12_Jeandesboz_Land_ sea_airborder.pdf [access: 1.03.2021]. 


\section{Bibliography}

A New Travel Authorisation for EU Visitors, https://etias.com [access: 1.03.2021].

Administracyjnoprawny status jednostki (wybrane zagadnienia), ed. M. Stych, Częstochowa 2012.

Australian Government, Department of Home Affairs, Immigration and citizenship, https:// immi.homeaffairs.gov.au [access: 1.03.2021].

Brabandt H., Mau S., Liberal Cosmopolitanism and Cross-Border Mobility: The Case of Visa Policies, Global Society 2013, vol. 27, no. 1, DOI: 10.1080/13600826.2012.734285.

Cesarz M., Communitarian and Intergovernmental Dimension of EU Visa Law, Review of European and Comparative Law 2019, vol. 37, no. 2, DOI: 10.31743/recl.4841.

Cesarz M., Polityka wizowa Unii Europejskiej jako metoda kontroli przekraczania granic, in: Unia Europejska $w$ poszukiwaniu swoich granic, ed. M. Trojanowska-Strzęboszewska, Warszawa 2017.

Dobrzańska B., Sitek M., Mini leksykon dyplomatyczny, Józefów 2011.

Dynia E., Ewolucja polityki migracyjnej Unii Europejskiej-wnioski de lege ferenda, in: Wobliczu kryzysu. Przyszłość polityki azylowej i migracyjnej Unii Europejskiej, ed. A.M. Kosińska, Lublin 2017.

European Travel Information and Authorisation System (ETIAS): Council Confirms Agreement with European Parliament, https://www.consilium.europa.eu/pl/press/press-releases/2018/04/25/european-travel-information-and-authorisation-system-etias-council-confirms-agreement-with-european-parliament/ [access: 1.03.2021].

Fall 2018 - ETIAS and Schengen Area Updates, https://etias.com/articles/fall-2018-etiasand-schengen-area-updates [access: 1.03.2021].

Gilboy J.A., Deciding Who Gets in: Decision Making by Immigration Inspectors, Law \& Society Review 1991, vol. 25, no. 3.

Goverment of Canada, Find out about Electronic Travel Authorization (eTA), https://www. canada.ca/en/immigration-refugees-citizenship/services/visit-canada/eta/facts.html [access: 1.03.2021].

Guild E., Moving the Borders of Europe, https://cmr.jur.ru.nl/cmr/docs/oratie.eg.pdf [access: 1.03.2021].

Guild E., Security and Migration in the 21st Century, Cambridge 2009.

Kuster B., Tsianos V.S., How to Liquefy a Body on the Move: Eurodac and the Making of the European Digital Border, in: EU Borders and Shifting Internal Security, Technology, Externalization and Accountability, eds. R. Bossong, H. Carrapico, Cham 2016.

Kosińska A.M., ETIAS czyli szczelne granice Unii, https://ec.europa.eu/poland/news/170201_ etias_pl [access: 1.03.2021].

Lee L.T., Quigley J.B., Consular Law and Practice, Oxford 2008.

Mau S., Brabandt H., Laube L., Roos Ch., Liberal States and the Freedom of Movement. Selective Borders, Unequal Mobility, London 2012.

Meloni A., EU visa Policy: What Kind of Solidarity?, Maastricht Journal of European and Comparative Law 2017, vol. 24, no. 5, DOI: 10.1177/1023263X17741272.

Meloni A., Visa Policy within the European Union Structure, Berlin-Heidelberg 2006.

Modrzejewski A., Charakter prawny wiz jednolitych krótkoterminowych w Unii Europejskiej, in: Status prawny cudzoziemca w Polsce, ed. M. Zdanowicz, Białystok 2007. 
Moreno-Lax V., Accessing Asylum in Europe: Extraterritorial Border Controls and Refugee Rights under EU Law, Oxford 2017.

Operational Practices of EU Entry Governance at Air, Land and Sea Borders, ed. J. Jeandesboz, ADMIGOV, Brussels 2020, https://admigov.eu/upload/Deliverable_D12_Jeandesboz_ Land_sea_airborder.pdf [access: 1.03.2021].

U.S. Customs and Border Protection, https://esta.cbp.dhs.gov/esta/ [access: 1.03.2021].

Salter M.B., Mutlu C.E., The 'Next Generation' Visa. Belt and Braces or the Emperor's New Clothes? Implications for the EU's Migration and Asylum Policies, CEPS Paper in Liberty and Security in Europe 2011, http://aei.pitt.edu/32548/2/No_44_Salter_Mutlu_on_ next_generation_visas_final.pdf [access: 1.03.2021].

Security Union: A European Travel Information and Authorisation System - Questions \& Answers, https://ec.europa.eu/commission/presscorner/detail/en/MEMO_16_3706 [access: 1.03.2021].

Vavoula N., European Travel Information and Authorisation System (ETIAS): A Flanking Measure of the EU's Visa Policy with Far Reaching Privacy Implications, Queen Mary School of Law Legal Studies Research Paper 2017, no. 256, https://papers.ssrn.com/sol3/ papers.cfm?abstract_id=2928082 [access: 1.03.2021].

Zawadzka S., System wjazdu i wyjazdu (EES) i Europejski system informacji o podróży oraz zezwoleń na podróż (ETIAS). Rola i znaczenie nowoczesnych systemów w zakresie działań prewencyjnych $i$ wzmacniania bezpieczeństwa UE, Bezpieczeństwo. Teoria i Praktyka 2019, no. 4, DOI: 10.34697/2451-0718-btip-2019-4-005. 
